\title{
MULTICULTURAL SOCIETY AND DEMOCRACY
}

\author{
Meri Kraja \\ PhD Candidate, Justice Department, Faculty of Law, "WISDOM" University, Tirana, Albania, \\ meri81al@yahoo.it
}

\begin{abstract}
Today, discussing about multiculturalism is a topic often abused and perhaps not sufficiently analysed. Debates never resolved have been brought to the centre of attention from religious fundamentalism to the problem of security, the relations with the sphere of individual freedom, privacy and freedom of movement and opinion as well as the theme of multi-ethnic society, integration, the coexistence of different religions and cultures. Which spaces of coexistence, such as prospects in which nodes must be solved in order to discuss about a society that is both democratic and multicultural? This paper aims at analysing how in global world societies become more heterogeneous and diverse, from the social point of view as well as from the ethnic, religious, and cultural point of view. Confusing Islam with terrorism, condemn a religion, to oppose the construction of its places of worship, would be to put in tol crisis the freedom of religion and that would make us equal to our "enemies". The clash of civilization is what terrorists are striving for. Another important aspect in which this paper is focused on, is how Europe should respond to all this. Will the EU grow to creating a real European democracy, able to guarantee development, security and solidarity, going towards a great diverse and pluralistic society? This paper aims to reflect on the essence of European civilization today under many attacks from inside and outside and understanding the challenges we are facing today. Culture and multiculturalism, must be an expression of mutual enrichment, foundation on which to build an existential path of tolerance and solidarity.
\end{abstract}

Keywords: Multicultural, Nationalism, Democracy, Society, Pluralistic.

\section{INTRODUCTION}

The history of mankind is marked throughout his career, from large exodus, who viewed the Mediterranean peoples, the peoples of East and West, South and North of the world cross entire continents and seas. In the last ten years, like a number of comparable countries in Europe and North America, has experienced public anxiety about the perceived threat to social cohesion from increasing ethno-cultural diversity ( $\mathrm{T}$. Dreher and C Ho, 2009, p. 2).

These anxieties gave rise to debates about whether policies of multiculturalism were inhibiting integration and social cohesion and in fact contributing to segregation (Modood. T, 2007, pp. 12-13.).

Most of these issues, such as the interaction between particular cultural practices and human rights discourses, the place of religion in the public sphere, the growth of religious extremism, or the persistence of inequalities faced by minority groups, relate to broader concerns about the meaning and relevance of culture, the parameters of multiculturalism within secular liberal democracies, the distribution of 
opportunities, resources and power in multicultural societies, and the construction of narratives of nationhood and national belonging.

Recent history shows the disenchantment towards the process of recognition of the others, often catalogued as the outsider and social equilibria disturber. Therefore the question is not: "Multiculturalism, yes or no?", but rather - as Norberto Bobbio (1996) said -"Which multiculturalism?".

Multiculturalism does not mean, not being tied to one's own culture, but rather means looking at the culture of the "other" with consideration and respect (Bonet.L, Négrier.E, 2010, p 7.).

To put it in the words of Gandhi "I do not want my house to be walled in on all sides and my windows to be stuffed. I want the culture of all lands to be blown about my house as freely as possible. But I refuse to be blown off my feet by any".

After September 11, 2001 and subsequent to the "infinite" war against terrorism, the considerations and the proclamations about "us" against "them" have been increased, while a deep furrow is being created between the different parts of the planet with the consequences and impacts on our democratic political systems, not yet completely defined (Maley. W, 2010, p.10).

By the beginning of the twenty-first century many European states appeared to be undergoing a so called "crisis of integration" as governments became concerned about the socio-cultural integration of immigrants, particularly those of Muslim background (Castles. S and Miller. M, 2010, p.79).

The presence of sizeable Muslim minorities in a number of European countries, fears of the growth of Islamic extremism and the perpetration of violent or terrorist acts in some societies were key factors catalyzing the concentration of public attention on issues of integration and social cohesion in Europe, (Wike. R and Grim. $B, 2006$, p.21).

The clash of civilizations theorized by Huntington (Huntington.S,1994), is likely to be materialize in many forms from which he had imagined, but that does not mean less dangerous.

A multicultural society, is a political society in which there is not a dominant cultural identity or majority, but there are at least two with equal rights to recognition. The problem of minorities, in fact, is specifically "within society" mono or plural multicultural ones where all cultures are not recognized in the same way (Bernardi.A, 2006, p.39).

We must therefore; clearly distinguish two types of multicultural societies: those in which there are always local indigenous cultures which aspire full assimilation leaving the minority ghetto, and one in which the phenomenon of immigration introduces new cultural entity aspiring to preserve their identity of origin (Shachar. A, 2001, p 273) and participating in the political life.

In other words, multiculturalism concerns social and political issues produced by the coexistence of different cultural identities in the same society as for example; the problem of "recognition".

The big challenge for contemporary democracies, seem to find acceptable solutions, ethically and politically feasible, allowing for a peaceful coexistence. In fact this is a problem, ancient and the same time modern, which threatens and complicates it further in the light of the complexity in this phase of history, exposing humans and the contemporary society to a double possibility: that of destructive conflict, and the possibility of meeting, or intercultural dialogue. There is also another aspect of the new boundaries.

The European Union is enlarging, but obviously this implies at the same time a reduction of national borders and a widening internal boundaries: no longer in the geo-political sense, but in sociological and cultural sense. The great community of peoples, living in the Union, nowadays is being recognized internally, the problem of coexistence of different ethnic, cultural and religious (Chistolini. S, 2006, p 18).

In Europe the diversity is a reality and that the continent cannot deviate from it, without betraying the basic democratic law.

\section{THE SPACE OF RACISM}

Many of the issues faced by multicultural societies today transcend national borders and raise broader questions about how liberal democracies are to respond to the challenges of diversity. 
As a concept and policy that was originally concerned primarily with linguistic and cultural diversity both in UE and overseas, how can multiculturalism deal with growing religious diversity and the issues raised by religious expression, often mediated by cultural practices, in secular liberal democratic spaces? Does multiculturalism have a role to play in addressing enduring social inequalities and the challenges faced by minority communities in diverse societies?

Beyond what is being thought, in fact, xenophobia and racism are not the legacies of the past that periodically have been resurfaced due to the marginal violence and extreme fringe.

As the sociologist Michel Wievorka implies, racism cannot be attributed only to its historical shapes more visible forms like the segregation of blacks, or the extermination of the Jews. Racism is that social process, which is politically and culturally produced by "discrimination", "internalization" and "exclusion" of the others, manifested in behaviors and in prejudices that slowly are been confirmed and consolidated socially and sometimes even institutionally (Wievorka.M,1993).

The source of the turmoil is Europe's collective perception of itself as a unitary civilization, not as individual countries or governments, and the sense that its cultural and civilizational identity is in danger.

The results of the International Social Survey Programme (ISSP) of 2003 revealed that in a number of European countries, including the UK, Germany, Norway and the Netherlands, over 70 per cent of respondents tended to come out in favor of strictly controlled or reduced immigration ((OECD), 2010, pp. 118-119).

Europe feels threatened not by the Muslims in its midst, but by an assertive Islam from within, which is determined to challenge the constitutive norms that make up Europe. The consequences we are living on our skin. The immigration phenomenon in Europe multiplies more and more each day the local conflicts, emerging strongly xenophobic political movements, where the different religious fanaticism are being feed (Donati. A, 2012, p.16).

To put it simply, the intransigent assertiveness of Islam inside Europe and its ability to have a transformative impact are threatening to unmake and remake Europe. Europeans are suddenly behaving towards Islam like a minority under siege that fears for its identity in the presence of a dominant majority culture.

Discussing about the need for a dialogue between cultures immediately comes in to mind the emerging problem of comparison between Western culture and Islam.

However, concerns about the place of Muslim communities in Europe are not limited to relatively recent fears about the growth of extremism, but are also related to more far-reaching and deep-seated issues of socioeconomic and ethnic marginalization facing Muslim minorities as well as other immigrant communities. Both the United Kingdom and France have at various times in recent decade experienced civil unrest which was symptomatic of the socioeconomic and ethnic exclusion of immigrant minorities (Castles.S and Miller. M, 2010, p.282).

This issue - placed not only in the international relations, but also coexistence with the increasing migrant communities -cannot be confused with that of terrorism. In some ways, because terrorism is an expression of an Islamist minority that cannot be confused with what the Islamic world represents. In this game there are not only European values, but also the outcome of the conflict inside Islam and States that are inspired by it, in which the shadow of the new Caliphate is being dragged.

The multiculturalist model provides, on the one hand, the reconsideration of the traditional meaning of the term "ethnic" of the citizenship status, on the other hand, a questioning of the old ' national character ' of the culture of modern State. Multiculturalism suggests the revision of parameters with which to measure national membership. The problem does not only affects the European States separately, but also arises in the overall European Union level.

\subsection{Cancellation of the Differences}

Democracy is a universally recognized ideal as well as a goal, which is based on common values shard by people through-out the world community irrespective of cultural, political, social and economic differences.

Multiculturalism is not only a social phenomenon, but above all a political project. Its specificity is aimed at establishing social integration via the public recognition of identity and culture "foreign" compared to traditional national framework. Being a political project makes multiculturalism a controversial and conflictual 
issue, but also at the same time, a source of renewal and revitalization of political and social institutions. But we have to take in to consideration the end of multiculturalism.

Recently both Angela Merkel and David Cameron have remembered how multiculturalism has substantially failed. The two European leaders expressed the importance and the necessity of a real and deep integration of young Muslim immigrants in European national societies.

However the failure of multiculturalism is clearly demonstrated, by the Netherlands case, which for a long time it was seen as a reference model. In the Netherlands, the idea that it was sufficient to grant freedom to all races and all religions in the name of cultural relativism turned out to be a utopia.

In her official biography, published in 2006, Queen Margrethe II of Denmark made provocative remarks that revealed her fear of Islam and her desire to "counterbalance" it:

We are being challenged by Islam these years ... There is something endearing about people who give themselves up completely to their faith. But there is likewise something frightening about such a totality, which also is a feature of Islam. A counterbalance has to be found, and one has to, at times, run the risk of having unflattering labels placed on you. For there are some things for which one should display no tolerance. And when we are tolerant, we must know whether it is because of convenience or conviction.

Yet the bet to a different multicultural citizenship is a prerequisite for Europe's future. Indeed, it is an ethical imperative that calls into question the responsibility for a different quality of life, especially for future generations (Riccardi. A, 2006, p.36).

While it is true that Europe has, on one hand, refused to be set up as a State-wide national, on the other hand, has proposed the secular-liberal core of the experience of the modern State: the public space must be secular and neutral, while religious faith and ethnic identity are things to be privately practiced. Recognition policies are the essence of multiculturalism: «multiculturalism» means that religious particularities ethnic, linguistic, etc., asking to be considered legitimate, even though; it does not conform to what is considered "national", it also requires to be represented in the public space and not be merely relegated to the private sphere.

Certainly, Europe could very well refuse to do this step, however the costs of such resistance toward this change could be greater than the reasonability of manage it.

It should not be forgotten that if Europe wants to become a society and not a simple partnership between States, cultural pluralism is inevitably marked in its fate. But even if, as some studious believe (Soysal 1994), multiculturalism is intended to be the most likely model of European society of the near future, it is nevertheless true that we do not know yet exactly where to begin to make it happen.

The riots in various parts of the world, and even in France, new cartoons by Charlie; but also the dutiful distance that was held after the dramatic story of cartoonists, journalists and policemen deaths to the editor of satirical newspaper Charlie Hebdo... well all this leads to a reflection on the attitude to have and to hold, in front of religious beliefs (whatever it is) that many people live deeply and genuinely (and other perhaps knows to use it for other purposes). We also realized, after the excitement of the early days of the massacre, that not everyone in France are "Charlie (Tiliacos.N, 2015, II mal francese, "IL Foglio").

Armed men dressed in black balaclavas are the new symbols of a shameful fact: the global light arms trade is potentially the killer of civil societies everywhere; in Ottawa, Sydney, Mumbai, Peshawar and now in Paris. There's another political fact here that shouldn't be overlooked. The bitter truth is that barbarism of the Paris kind is the poisonous fruit of the so-called war on terror. Just a few hours after the attack on Charlie Hebdo, Bernard Cazeneuve, again quick off the mark, said that the attacks confirmed the need for a widened "global war on terror". This way of thinking contains an inner flaw that is literally fatal.

But what is, today France? It's really the "sick of Europe", as in the past few years has been argued, both inside and outside the country?

How it happened that the country that represents the human rights has woken up one day turned into the first European nation from which Jews immigrate to Israel?

Seventy years after the liberation of Auschwitz, the fear has returned to dominate the lives of French Jews! 
The French model has attempted to delete the cultural diversity and to eliminate the ethnic and religious membership, trying to consider everyone "Frenchmen" to naturalize everyone who lives in France. The public sphere is the sphere of sharing (more or less forced) values, which are the values of the French tradition, and which are partly traditional liberal values, but always filtered by a centralist State and "identity". The result is a process of integration which tends to erase ethnic and cultural identity in favors of a homogeneous society and "French".

France has been focused on the absolute égalité, eliminating each difference on sterilization of any identity, making a clean sweep of every outward sign of religion.

A version of laïcité that today has been discovered as fragile compared to Islam: the French are trying to work in a field with the same tools that have been used in the past but in a different and developing context, but not necessarily for their fault (Žižek.S, 2012, p.37).

But we must understand that frustration must be fought with massive doses of multicultural recognition of equality among differentiates. Absolute security is outside the possibilities of the EU.

We should not frame our society into a "security state". The 20th century had in democracy its victorious party. Europe and the West cannot deny others the right to God (laïcité) nor restore their God.

A century ago, Gilbert Keith Chesterton clearly deployed the fundamental deadlock of the critics of religion:

Men who begin to fight the church for the sake of freedom and humanity end by flinging away freedom and humanity if only they may fight the church ... The secularists have not wrecked divine things; but the secularists have wrecked secular things, if that is any comfort to them.

We cannot say the same thing for the advocates of religion themselves. How many fanatical defenders of religion started out attacking secular culture and ended up forsaking any meaningful religious experience? In a similar way, many liberal warriors are so eager to fight anti-democratic fundamentalism that they end up flinging away freedom and democracy only to fight terrorism. If the "terrorists" are ready to wreck this world for love of another world, our warriors are ready to wreck their own democratic world out of hatred for the Muslim.

\section{THE EUROPE OF EXCLUSION}

What if Europe accepted the paradox that its democratic openness is based on exclusion?

And if we were really entering a new era in which this type of reasoning will impose itself? "There is no freedom for the enemies of freedom ", as Robespierre put it long ago? (Žižek. S, (2012), p.37).

What we understand as well that the reality of multiculturalism can radically change the face of constitutional democracies.

Although the current crisis in the European Union appears to be economic and financial type, in its fundamental dimension is a political-ideological crisis: the failure of the referendum on the European Constitution, a few years ago, was a clear signal that the voters perceived as an economic Union "technocratic", without any vision that could involve the populations.

From France to Germany, from Austria to Holland, in the new spirit of pride for their historical and cultural identity, now the parties are accepting and stress that immigrants are guests who have to adapt to the cultural values of the society that receives them: "This is our country, take it or leave it".

Some argued that the aim of introducing tighter measures was to exclude security risks and target Islamic groups in particular (S Carrera, 2010, pp. 6-10). In many cases such measures forged a nexus between integration, and immigration and citizenship by imposing mandatory civic integration programmes and tests as a prerequisite for the acquisition of residential or citizenship status within the receiving country.

Attempts to defend national identity have also manifested in controversial and highly politicised public debates about restricting symbolic expressions of diversity, with recent debates being largely preoccupied with symbols of Muslim cultures. In November 2009 the Swiss people overwhelmingly voted in favour of a proposal from the far-right Swiss People's Party (SVP) to introduce a national ban on the construction of

Europe must move beyond mere tolerance, The EU must unite its people in a common struggle, breaking the deadlock between anaemic liberals and impassioned extremists, http://www.theguardian.com/commentisfree. 
minarets on mosques (Cumming Bruce. $\mathrm{N}$ and Erlanger. S, 2009). The success of the referendum was seen as reflecting fears of Islamic fundamentalism among the Swiss population.

Political elites who have misrepresented Islam, may have found it electorally beneficial to do so but in the long run this has been deeply damaging to social cohesion.

Debates about these issues related to broader concerns about the extent to which particular religious and cultural practices, seen by some as infringing upon human rights or the principles of liberal democratic societies, such as secularism and gender equality, could be tolerated in liberal democracies, and the extent to which states characterised by ethno-cultural and religious heterogeneity are willing to extend their national identity to encompass minorities.

Even more disturbing is the fact that the European Union continues to consider migration as a security problem (of terrorism) and not as a question of world politics and human rights. The closure of borders in this regard seems to go towards a new form of «lock» continental identity far away from a perspective of a progressive expansion of its citizenship. The debate in Europe is divided on other issues.

The first related to the ability of Islam to adapt to Western democratic institutions. The second issue which is also the most discussed - whether Islam is part of European history and culture.

The future of democracy is facing a crossroads: on one hand, taking the road to closure with toward the challenges that immigration brings with it, of the other hand, a renewal of the public sphere through a close comparison with the global reality, from below building forms and institutions of globalization and new cosmopolitanism.

The global political context pushes toward many perspectives which are worrying in many respects, where the conflict and hatred appear to have the upper hand.

The multicultural ideology of recent decades has led to a relativism of the reference values. It has created a multicultural relativism that is often wrongly confused with cultural pluralism. According to multicultural relativism there is no longer any difference between cultures and civilizations, there is an instinctive magma, according to which we are all equal regardless of our history and tradition. In a not-too-distant future, in our society, it would be tended to coexist more and more groups of nationalities and religions. And this is a perspective that we cannot deny, but it is essential to try to determine how the Western society and European will be confronted with the concrete perspective of a society that consists of a set of parallel cultural and religious microcosms.

Finally, European powers must profoundly re-examine the moral basis of their policies towards the Muslim world. It is in the interest of the new Europe to have a new relationship with the Muslim world, one based on mutual respect and co-operation. The new Europe's domestic structure no longer supports an imperial foreign policy. By what values system and with what ideas they will propose this society will face with the growing number of cultural and religious competitors. In a future melting-pot in which conditions we'll get? Just absolutely indisputable values, democracy, freedom and human rights or is it necessary to add to these something deeper? A system of values, a way of life, a culture that may represent the paradigm of a civilization to which the immigrant could find, possibly, a new identity and citizenship?

\section{CONCLUSION}

Globally, migration is a growing and increasingly complex phenomenon as people are moving and forging connections between countries in rapidly evolving ways (Castles. S and Miller. M, 2010, pp.2-7).

Reconsideration of the principles of constitutional democracies could ensure an acceptable integration of many ethnic communities, religious, cultural inhabiting Western societies. A multicultural society is a society that over-rides differences of race, gender, class, generation, and geography, and ensures inclusion, equality of opportunity as well as capability of all members of the society to determine an agreed set of social institutions that govern social interaction. (Expert Group Meeting on Promoting Social Integration, Helsinki, July 2008).

The result of this process of integration would be then a democracy that should no longer be "exported", but that could become the valid interlocutor of other civilizations and cultures, as would be the result of the interaction with other civilizations and cultures. There are in particular the processes of integration of Muslims in Europe who can represent the model of a dialogue among civilizations. It is an encounter still 
problematic that appears to be still exposed to risks and uncertainties. Must be a process of integration and adaptation, i.e., compatibility with the constitutional realities of European countries rather than assimilation. Is the prospect of euro-Islam (Tibi. B, 2003, Euro-Islam, p.103).

A solution that also opposes the concept of a set of parallel societies, separated by ethnic principle (Raz. J, 1994, p.67). Islam in Europe is therefore looking for different paths, of its own identity which can be reached through a deep contamination of civilizations and cultures that belong to the two shores of the Mediterranean. To achieve the latter goal complex and to build a story really supportive, you must first deconstruct authoritarian structures of thought and the intolerant ways of living. The true antidote to fear of the other, fear of immigrants, fear of Islam, is not security, prohibition policies, xenophobic policies, the introduction of increasingly police measures limits human liberties; the real antidote today is the ability to trust in the capacity of self-trust (De Vita. R, Berti, F, Nasi. L, 2005, p.308.).

In the context of increasing diversity, the question remains as to how multiculturalism can be meaningfully engaged with, and whether such engagement can contribute to the development of new concepts that can enable more productive public discourses about the challenges and transformations resulting from increasing diversity.

Democracy aims essentially to preserve and promote the dignity and fundamental rights of the individual, to achieve social justice, foster the economic and social develop-met of the community, strengthen the cohesion of society and enhance national tranquility, as well as to create a climate that Is favorable for international peace. As a form of government, democracy is the best way of achieving these objectives; it is also the only political system that has the capacity for self-correction.

\section{REFERENCE LIST}

Bernardi. A, (2006), Multiculturalism, human rights, punishment, criminal law Journals international and European comparative "international criminal law, Guiffre Editore, p 39.

Bobbio, N. (1996), The Age of Rights, Cambridge: Polity Press.

Bonet. L, Négrier. E, (2010), The end of national cultures? Cultural policies to meet the challenge, diversity Armando editore. Roma, p 7.

Calma. T, (2007), Multiculturalism: A position paper by the Acting Race Discrimination Commissioner, Human Rights and Equal Opportunity Commission (HREOC), Sydney, pp.1, 12-13.

Carrera. S, 2010, "A comparison of integration programmes in the EU: trends and weaknesses", Liberty \& Security Challenge Papers, no. 1, March 2006, pp. 1, 6-10, viewed 26 July

Castles. S and Miller. M, The age of migration: international population movements in the modern world, pp. 2-7, 47-48;

Chistolini. S, (2006), Citizenship and civil society in the European school,: essays in honor of Luciano Corradini, Armando Editore, Roma, p 18.

Cleaver. H, (2006), "We Need a Counter-Balance to Islam, Says Danish Queen”, Daily Telegraph (London), 17 February.

Collins. J, (2007), "The landmark of Cronulla", in Jupp.J and Nieuwenhuysen.J, Social Cohesion in Australia, Cambridge University Press, Melbourne, p. 61.

Cumming Bruce. $\mathrm{N}$ and Erlanger. S, "Swiss Ban Building of minarets on mosque", The New York Times, 30 November 2009.

De Vita. R, Berti.F, Nasi.L, (2005), Democracy, secularism and multi-religious society, Franco Angeli, Milano, p.308.

Donati, A. (2012). Immigration and multiculturalism: the reasons opponents, Armando, Roma, p.16.

Dreher.T and C Ho, (2009), 'New conversations on gender, race and religion.

Dreher.T, Ho. C, Beyond the hijab debates: new conversations on gender, race and religion, Cambridge Scholars Publishing, Newcastle upon Tyne, United Kingdom, p. 2.

Grewcock. M, Border, (2010), Crimes: Australia's war on illicit migrants, pp. 152 - 167. 
Hugo.G, (2010), A new paradigm of international migration: implications for migration policy and planning in Australia, Research Paper No. 10, 2003-04, Parliamentary Library, Canberra, pp. 17-18,

Huntington.S, (1994). The clash of civilizations, Milano, Garzanti.

Maley. W, (2010), Fear, Asylum, and Hansonism in Australian Politics, Dialogue, vol, 29/2.

Modood. T, (2007), Multiculturalism - a civic idea, Polity Press, Cambridge, pp. 12-13.

Organisation for Economic Cooperation and Development (OECD), 2010, International migration outlook, OECD, pp. 118-119.

Raz. J, (1994), Multiculturalism: a Liberal Perspective, “Dissent", p. 67.

Riccardi. A, (2006), Convivere, Laterza, Roma-Bari.

Shachar. A, (2001), Two Critiques of Multiculturalism, Caedozo Law Review,p 273.

Soysal. Y. N, (1994) Limits of Citizenship Migrants and Postnational Membership in Europe, The University of Chicago press, London.

Tibi, B. (2003). Euro-Islam. Lack of integration, Venezia, p.103.

Tiliacos, N. (2015). II mal francese, "il Foglio".

Wievorka, M. (1993). The Space of Racism. Milano: II Saggiatore.

Wike, R. and Grim, B. (2010). "Western Views towards Muslims: Evidence from a 2006 Cross-National Survey". International Journal of Public Opinion Research. 22 (1).

Wood, A. (2007), "Multiculturalism Becomes Poison for Social Capital". The Australian, 26 September.

Žižek, S. (2012). The Year of Dreaming Dangerously. Brooklyn: Verso. 